\title{
Елена ОСТРОВСКАЯ
}

\section{ЛЭНГСТОН ХЬЮЗ В ПЕРЕПИСКЕ С ЖУРНАЛОМ «ИНТЕРНАЦИОНАЛЬНАЯ ЛИТЕРАТУРА»}

Аннотация: В настоящей статье рассматривается один из эпизодов в эпистолярных отношениях американского чернокожего поэта Лэнгстона Хьюза с журналом «Интернациональная литература» - переписка с редакцией 1934-1937 годов - и публикуются письма к Хьюзу Уолта Кармона, американского редактора журнала в 1933-1936 гг., и Сергея Динамова, главного редактора журнала в 1933-1937 гг. Предлагаемая перспектива - переписка не с частными корреспондентами, а с институцией (литературным журналом, аффилированным сначала с международной, а потом советской писательскими организациями) - новая для обширной переписки Хьюза, опубликованной лишь в виде избранных томов, предоставляет возможность по-новому поставить вопрос об отношениях Хьюза с СССР.

Ключевые слова: Лэнгстон Хьюз, СССР, «Интернациональная литература», Уолт Кармон, Сергей Динамов, переписка, советско-американские литературные контакты.

() 2017 Елена Сергеевна Островская (канд. филол. наук, доцент; Национальный исследовательский университет «Высшая школа экономики», Москва) esostrovskaya@ hse.ru

\section{Elena OSTROVSKAYA}

\section{LANGSTON HUGHES IN CORRESPONDENCE WITH “INTERNATIONAL LITERATURE" MAGAZINE}

Abstract: The article examines an episode in the correspondence between the African American poet Langston Hughes and "The International Literature" magazine: 1934-7 letters to Hughes from Walt Carmon, an American editor of the journal in 1933-1936, and Sergey Dinamov, Editor-in-chief in 1933-1937. An epistolary relationship with a literary institution (a journal affiliated first with an international and then a Soviet writers' organization) rather than individual private correspondents offers a new perspective on Hughes' extensive epistolary corpus, so far published only in selected volumes, and his relations with the USSR.

Key words: Langston Hughes, USSR, "International Literature", Walt Carmon, Sergey Dinamov, correspondence, Soviet-American literary contacts.

(C) 2017 Elena S. Ostrovskaya (PhD, Associate Professor; National Research University Higher School of Economics, Moscow) esostrovskaya@ hse.ru 
Эпистолярное наследие Лэнгстона Хьюза «столь обширно, что его легко хватило бы на 20 томов $^{1} \gg$, - так начинается редакторское предисловие к основному на сегодняшний день собранию писем американского поэта [Rampersad, Roessel, \& Fratantoro 2015: 29]. В основе подборки принцип литературно-биографический: составители стремились выстроить эпистолярную параллель к автобиографическим книгам Хьюза «Большое море» (“The Big Sea”, 1940) и «Странствую и вопрошаю» (“I Wonder as I Wander”, 1956) [Rampersad, Roessel, \& Fratantoro 2015: 29]. Предыдущие издания переписки Хьюза основывались на иных принципах - не многочисленных монологов, адресованных различным адресатам, но одного диалога: Хьюза с Арной Бонтаном [Bontemps \& Hughes 1980] и Карлом ван Вехтеном [Hughes \& van Vechten 2002] - или нескольких диалогов [Hughes 2010]. Вероятно, на самых неожиданных основаниях - дружески-семейных - покоится подборка последнего издания эпистолярия поэта, публикация его переписки с семьями Паттерсонов и Кроуфордов, подготовленная и прокомментированная Мэри Луизой Паттерсон, дочерью Уильяма и Луизы Паттерсонов, и Ивлин Луизой Кроуфорд, дочерью Мэтта и Ивлин Кроуфордов [Hughes 2016].

Предлагаемый эпистолярный эпизод представляет собой еще один подход к творчеству и биографии поэта - через призму институциональной истории, на сей раз советского многоязычного издания «Интернациональная литература» (1932-1945). В архиве журнала (точнее, в разрозненных архивных делах, из которых складывается архив журнала в РГАЛИ) сохранилась переписка/фрагменты переписки Лэнгстона Хьюза с тремя сотрудниками редакции журнала: Сергеем Динамовым (главным редактором в 1933-1937 гг.), Уолтом Кармоном (редактором (editorial assistant) английской версии журнала в 1933-1936 гг.) и Тимофеем Рокотовым (и.о. главного редактора, 1938-1942² гг.); а также переписка Уолта Кармона, уже покинувшего пределы СССР, с Борисом Сучковым (ответственный редактор русской версии 1942-1943 гг.) $)^{3}$, посвященная Хьюзу. Достаточно небольшой объем документов позволяет прочертить сюжет взаимоотношений Хьюза с журналом и его сотрудниками уже после отъезда поэта из СССР и поместить этот сюжет, с одной стороны, в контекст изучения эпистолярного наследия Лэнгстона Хьюза, а с другой стороны - институциональной истории журнала «Интернациональная литература», а также, возможно, добавить несколько штрихов к биографии

\footnotetext{
${ }^{1}$ Перевод с английского здесь и далее мой. - E.O.

2 Для английской версии - 1938-1941 гг.

3 РГАЛИ. Ф. 1397. Оп. 1. Ед. хр. 957; Ф. 631. Оп. 14. Ед. хр. 1092.
} 
Уолта Кармона, отчетливо второстепенного деятеля радикальной левой прессы США [Wald 2002: 361]. Настоящая статья посвящена переписке Лэнгстона Хьюза с редакцией журнала 1934-1937 гг.; это была еще редакция, как он ее застал в Москве, и люди, с которыми его связывали личные отношения. В приложении публикуются письма Уолта Кармона к Лэнгстону Хьюзу 1934-го г. ${ }^{4}$ и русский черновик письма Сергея Динамова Лэнгстону Хьюзу, повидимому, 1937-го года ${ }^{5}$.

\section{Предыстория: Лэнгстон Хьюз в СССР}

История поездки Лэнгстона Хьюза в СССР в июне 1932 июне 1933 года хорошо известна и многократно описана как самим поэтом, так и его биографами и исследователями: сначала в многочисленных эссе и репортажах с места событий, активно публиковавшихся в периодической печати СССР и США и в виде книг ${ }^{6}$, а позднее в его второй автобиографической книге "Странствую и вопрошаю» (I Wonder as I Wander, 1956), от которой так или иначе отталкиваются биографы и исследователи [Rampersad 2002, Leach 2004, Baldwin 2002, 2007]. Как правило, центральное место в повествовании отводится истории с проектом несостоявшегося фильма "Black and White" - драматургически, разумеется, самому яркому московскому эпизоду [Rampersad 2002: 242$254]^{7}$ или восточному путешествию поэта, запоминающемуся своим колоритом [Moore 2002; Baldwin 2002; Baldwin 2007]. Последующие московские месяцы Хьюза, его «Весна возле Кремля» (так называется раздел автобиографии, посвященный первой половине 1933 г.), более литературоцентричны и выступают скорее в качестве фона и материала для комментариев.

${ }^{4}$ РГАЛИ. Ф. 1397. Оп. 1. Ед. хр. 957. Л. 1-4.

5 Там же. Л. 22.

6 Хьюз опубликовал серию статей в «Известиях» и «Интернациональной литературе» в 1932-1933 гг. В 1934 они были собраны в книгу «Негр смотрит на советскую Среднюю Азию» (“А Negro Looks at Soviet Central Asia”) и опубликованы в Москве [Hughes 1934]. По возвращении в Америку Хьюз продолжал писать о Средней Азии и напечатал ряд эссе в разных американских изданиях, от радикального журнала "New Masses" и до глянцевого журнала "Travel" [Moore 2002: 1119].

${ }^{7}$ Организатором группы из 22 человек стала Луиза Томпсон (Паттерсон), и именно в Москве окрепла дружба Хьюза с Паттерсонами и Кроуфордами, что и нашло отражение в книге переписки с Хьюзом "Letters from Langston: From the Harlem Renaissance to the Red Scare and Beyond" [Hughes 2016]. 


\section{"I Wonder as I Wander"}

Появление Хьюза в Москве в середине декабря 1932 г. не находит отражения в его печатных репортажах с места событий, из Москвы 1933 г., но ярко описывается в "I Wonder as I Wander". После полного приключений путешествия по Средней Азии и знакомства с ее «цветным» населением поэт приезжает в замерзшую Москву в середине ночи, нагруженный подарками гостеприимного Востока. Однако выясняется, что срок действия его визы истек накануне, администратор отказывается поселить его в гостинице и, благодаря свойственной ему настойчивости, поэту удается расположиться на ночлег на креслах в фойе.

In the morning [...] I went to the Writers Union to see about getting my travel permit renewed.

At the Writers Union I found Walt Carmon, the amiable American editor of the English language edition of "International Literature", who start[ed] the wheels turning for me to get my permit renewed and solved the problem for me by inviting me to stay with him and his wife. ${ }^{8}$ [Hughes 2003: 203]

Утром я отправился в Союз писателей, чтобы договориться о продлении моей визы. В Союзе писателей я встретил Уолта Кармона, обаятельного американца-редактора английского издания «Интернациональной литературы», который запустил механизм продления моей визы и разрешил мою проблему [с жильем], пригласив меня пожить у них с женой.

Книга Хьюза строится как плутовской роман, где на стержень пути нанизываются анекдотические истории, что определенным образом выстраивает характер главного героя и отчасти других персонажей. Так, рассуждая о Кармоне, Хьюз не уделяет особого внимания своему сотрудничеству с журналом, главным образом подчеркивая суммы гонораров (весьма внушительные) и невероятные сложности с их получением, причем и то, и другое мыслится им как универсальные отношения поэта с Советской властью.

But it was mere child's play getting a piece of paper to wrap bread as compared with getting the proper papers to be entitled to have bread or a room, or to travel, or to collect money after one had earned it as a free-lance writer. I did a number of articles on my trip to Central Asia for "Izvestia", "International Literature", and other Moscow publications. [...] it took a great deal of time and patience, but eventually I would emerge from a pub-

8 Здесь и далее книга Л. Хьюза приводится в переводе, выполненном автором статьи и Викторией Буяновской, студенткой 4 курса бакалавриата ФГН НИУ ВШЭ. 
lishing office with a whole bundle of rubles, paid at last. I made more from writing in Moscow in terms of buying power than I have ever earned within the same period anywhere else. [Hughes 2003: 205]

Но добыть лист бумаги, чтобы завернуть хлеб, было сущим пустяком по сравнению с получением бумаг, необходимых для того, чтобы получить хлеб или комнату, или путешествовать, или забрать деньги, заработанные в качестве гонорара. Я написал серию статей о своих путешествиях по Центральной Азии для «Известий», «Интернациональной литературы» и других московских изданий. [...] На это требовалось время и терпение, но в конце концов я выходил из издательства с пачкой наконец выплаченных мне рублей. Как писатель, я заработал в Москве больше, чем где бы то ни было за то же самое время, если измерять покупательную способность.

Надо сказать, что тема гонораров с не меньшей настойчивостью присутствует и в письмах поэта из Москвы, впрочем, специально подобранных составителями тома переписки. Материальная составляющая в них прописана более контрастно: поэт счастлив бежать от Великой депрессии и наслаждается своими гонорарами, каких он не получал никогда в жизни. Ср. в письме Ноэлю Салливану:

This is the only place I've ever made enough to live on from writing. Poets and writers in the Soviet Union are highly regarded and paid awfully well; as a class, I judge, the best cared for literary people in the world. And books sell [like] hot cakes. Usually ten days after a new book has appeared, not a copy can be found. And in spite of the paper shortage, they print large editions. Imagine in America, 10,000 copies of anybody's book of poemsas a first edition. And that is common here! And then come the translations into all the minorities' languages [...]. [Hughes 2015: 182]

Мне нигде раньше не удавалось зарабатывать себе на жизнь тем, что я пишу. В Советском Союзе поэтов и писателей высоко ценят и им чертовски хорошо платят; я бы сказал, нигде в мире так не заботятся о литераторах. И книги продаются [как] горячие пирожки. Обычно через десять книг после выхода книги уже нельзя найти ни одного экземпляра. И несмотря на дефицит бумаги они выходят большими тиражами. Представьте себе в Америке 10000 экземпляров тираж сборника стихов - первого издания. И это здесь обычное дело! А потом выходят переводы на все языки меньшинств [....]

\section{и Прентисс Тейлор:}

I shall more than likely become a wolf myself when I return to America, what with the books not selling and the jobs to be had nowhere. I don't even know why I am coming back. I've never lived better than here, or sold more work for actual cash, even if it is not changeable in capitalistic lands. [Hughes 2015: 186]. 
Я, скорее всего, и сам стану волком, когда вернусь в Америку, если книги не продаются и работу не найти. Я даже не знаю, зачем я возвращаюсь. Я никогда не жил так хорошо и не продавал столько произведений за реальные деньги, хотя их и не принимают в капиталистических странах.

Московские страницы автобиографии состоят из анекдотов о советской жизни, увиденной глазами чужака, выходца из капиталистического мира, и галереи коротких портретов литераторов московских знакомых поэта. Большинство из них так или иначе связаны с «Интернациональной литературой» - это члены редколлегии или авторы. В книге фигурируют Сергей Третьяков (главный редактор русской версии журнала, драматург, автор пьесы «Рычи, Китай!»); Юлиан Анисимов (член редколлегии журнала) - «писатель, критик и лирический поэт» (“writer, critic and lyric poet”) и, конечно, переводчик стихов Хьюза; он же знакомит поэта с автором критического (во всех смыслах) отзыва о его творчестве Лидией Филатовой (“"he] introduced me to a very bright young woman, Lidya Filatova, his protégée, who wrote brilliant critical articles"). ${ }^{9}$ [Hughes 2003: 207]

Помимо русского круга общения, Хьюз описывает и московских космополитов (“worldings"):

In Moscow, too, that year my paths crossed the paths of such worldlings as the French poet and novelist Louis Aragon and his lovely writerwife, Elsa Triolet; the Chinese poet Emi Sao; the Japanese theater director Seki Sano; the hard-drinking British poet Charles Ashleigh; the brilliant but dogmatic Negro Lawyer William Patterson [...]; and dozens of English and American tourists coming and going [...]. [Hughes 2003: 218].

В Москве же в это время мои пути пересекались с такими космополитами, как французский поэт и романист Луи Арагон и его очаровательная жена, писатель Эльза Триоле; китайский поэт Эми Сяо; японский театральный режиссер Секи Сано; сильно пьющий британский поэт Чарльз Эшли; блистательный, но догматичный негр-адвокат Уильям Паттерсон; [...], и десятками английских и американских туристов, которые приезжали и уезжали...

Любопытно, что в мемуарах Хьюз последовательно придерживается амплуа плута - пикаро или, если обратиться к терминологии Марка Липовецкого, трикстера - чужака, постоянно остраненного и отстраненного от советской реальности и, в то же вре-

9 «Превосходная» статья Лидии Филатовой «Лэнгстон Хьюз» посвященная творчеству Хьюза, была опубликована как в русскоязычном (1932, № 9-10), так и в англоязычном (1933, № 1) номерах «Интернациональной литературы». 
мя, в достаточной степени наблюдательного, чтобы обнажать механизм ее функционирования. Марк Липовецкий, посвятивший книгу явлению, или точнее, фигуре, которую он называет «советским трикстером», рассматривает ее в непосредственной связи с «проблемой советской модерности и ее специфических черт» [Lipovetsky 2016: 13]. Безусловно, если читать мемуары Хьюза как плутовской роман, а в герое видеть «натурализованного» трикстера-иностранца, становится понятным, почему она посвящена не столько литературе, сколько литературной жизни, а главное приключениям и авантюрам рассказчика.

\section{Лэнгстон Хьюз и «Интернациональная литература»}

Первая публикация Хьюза в предшественнике «Интернациональной литературы», журнале «Литература мировой революции», состоялась еще до его приезда, в последнем номере за 1931 г. (на русском языке). А в течение шести месяцев пребывания поэта в Москве в конце 1932 - начале 1933 гг. его имя можно увидеть во всех номерах английского издания журнала и во многих русских номерах.

Оставив Москву, он какое-то время продолжает быть постоянным автором журнала: в основном, его стихотворения в переводе печатаются в русской версии издания. Так, в 1934 году там были опубликованы «Воровская песнь», «Баллада о Мэри», «Медные плевательницы», «Блюстители закона стучатся в мою дверь» и разоблачительный очерк «Уолтер Уайт - белый негр»; в 1935 году - две повести, «Дома» и «Бери», стихотворение в подборке «Негритянская поэзия» и небольшой биографический очерк о Джесси Фоссет (1935). Кульминацией стал 1936 год, когда вышла «Баллада о Ленине», один из самых «красных» поэтических текстов Хьюза. В дальнейшем его имя появляется на страницах журнала уже в разделе хроники или ее многочисленных производных.

Почему, хотя Хьюз остается идеологически важной фигурой среди американских чернокожих левых литераторов, он практически перестает публиковаться в журнале? Что это, изменения в политике журнала или предпочтениях редакторов? Технические сложности с пересылкой текстов или гонораров? Изменения стратегий публикации поэта? И как вообще складывались отношения Хьюза с редакцией журнала после того, как поэт сел в Транссибирский экспресс и отправился на Дальний Восток? Переписка поэта с сотрудниками журнала позволяет пролить свет на эти вопросы. 


\section{Лэнгстон Хьюз и Уолт Кармон: письма Кармона к Хьюзу 1934 г.}

Американский леворадикальный журналист Уолт Кармон, как и Лэнгстон Хьюз пережидал в Москве Великую депрессию. Пиком его карьеры, как правило, считается период 1929-1932, когда он был главным редактором журнала "The New Masses". В 1932 г. его сместили с этого поста, и он переехал в Москву, как и некоторые другие американские левые радикалы. Немногочисленные работы американских ученых, которые удостаивают его упоминанием, рисуют его алкоголиком, случайно оказавшимся в кресле главного редактора и благополучно канувшим в небытие вскоре после возвращения из СССР. Так, Алан Уолд следующим образом описывает последние годы жизни журналиста: «По возвращении в Соединенные Штаты он сначала работал представителем каких-то советских издательств, а потом жил в безвестности с женой Роуз и на момент смерти работал бухгалтером в НьюДжерси» [Wald 2002: 361].

B “I Wonder as I Wander" Уолту Кармону также отводится роль скорее второстепенная, однако весьма своеобразная, настолько отчетливо являющаяся функцией сюжета, а не личности, что велик соблазн интерпретировать этот образ как волшебного помощника из волшебной сказки по Проппу или чужака, трикстера, уже интегрированного в советскую систему по Липовецкому. Его умение запустить бюрократическую машину (start the wheels turning) и готовность приютить поэта разрешают ситуацию, казавшуюся безнадежной. Дальнейшие страницы, связанные с ним, еще интереснее: они рисуют быт Москвы начала 1930-х гг. и, одновременно, «американской колонии»: американцев, которые живут не в гостинице, как Хьюз, когда документы у него в порядке, а в обычной московской квартире. В главе с многозначительным названием «Хлеб, бумажная волокита и поэты» имя Кармона упоминается исключительно как часть фонового описания -

I simply stayed on with Walt and Rose Carmon, those two genial souls who had a single room with a family from Brooklyn in a new Soviet apartment house. [Hughes 2003: 204]

[Я] просто остался у Уолта и Роуз Кармон - эти добрые души жили в одной комнате в новом советском многоквартирном доме в одной квартире с семьей из Бруклина.

или присутствует в ситуации именно как имя, например, владельца продуктовых карточек: 
I remember once, Rose and I saw the butcher stalls piled with ducks and decided to combine our ration coupons and have a duck for dinner. But her coupons, mine, and Walt's were not quite enough for a whole duck. [Hughes 2003: 205]

Я помню, как однажды мы с Роуз увидели мясной прилавок, на котором сгрудились утки, и решили объединить наши талоны и заполучить на ужин утку. Но моих, ее и Уолта купонов не хватило на целую утку.

О других обитателях квартиры, в которой Кармоны были квартирантами, «семье из Бруклина», сегодняшний читатель больше узнает из комментариев. Зять «семьи американских евреев» - хозяев, у которых Кармоны, согласно Хьюзу, снимали комнату Джек Чен, сын Юджина Чена, экс-премьер-министра Китая, и брат Сильвии Чен - балерины и адресата самых романтических писем Хьюза из всех, дошедших до нас [Rampersad 2015: 25-26] ${ }^{10}$. Брат и сестра Чен - второстепенные, но неизменные персонажи как писем Хьюза из СССР, так и позднейшей его переписки с тогдашними друзьями.

Письма Кармона Хьюзу 1934 г. (от 26 октября, 9 и 29 декабря) приоткрывают иной аспект отношений: дружеских, шутливых, с обсуждением стихов и жизни вокруг, не только и не столько продуктовых карточек. Игривый тон автора писем вполне соответствует атмосфере московской жизни Хьюза, которую передает и мемуарная книга, а с другой стороны, отражает свойственный самому поэту стиль общения. Арнольд Рэмперсед, биограф и публикатор поэта, описывает интонационный репертуар зрелого эпистолярия поэта через преобладание в нем жизненной силы (vitality), упорства, сострадания и юмора [Rampersad 2015: 13]. В письмах Кармона к Хьюзу отчетливо доминируют жизненная сила и игривый юмор. Здесь шутливые дружеские обращения ("уou little shrimp", "you little bastard") и угрозы прогрызть дырки в книгах ("bite a hole in some of the books") или дать поощрительный пинок ("you've got a kick in the pants"), семейные и дружеские новости довольно тесного круга (Джек и Сильвия Чены, Фред и Этель Эллис), ироничные высказывания о журнале, который Кармон именует «листками» (sheets) соседствуют с обсуждением практических и творческих вопросов. Кармон одновременно выступает как редактор, обхаживающий важного автора, друг, который пристраивает стихи поэта в

${ }^{10}$ Краткая биографическая справка о Сильвии Чен представляет собой выжимку из биографии Хьюза Рэмперседа: занималась современным танцем и познакомила Запад с элементами китайского танца. После того, как в 1935 г. она вышла замуж за историка кино Джея Лейда, с которым познакомилась в Москве, она переехала в США. [Rampersad 2002: 264; Rampersad 2015: 25-26]. 
разные издания («Литературная газета» и “Moscow Daily Mail”), a также раздает туманные обещания без названия конкретных изданий, и критик - когда восторженный, когда более суровый. Любопытно, что настойчиво подчеркивающий важность верности левой идее и идейной твердости Кармон критикует рассказы Хьюза «Сын Ойстера» (“Оyster's Son”) и «Моряк и стюард» (“The Sailor and the Steward”) за эстетику агитпропа. Немаловажно также, что разговор о стихах и их критические оценки не отделяются Кармоном от дружеской части беседы: в качестве второго критика, впрочем, удивительным образом разделяющего его позиции, выступает Роуз, жена Кармона, которая в "I Wonder as I Wander" фигурирует в основном в походах по магазинам и никогда в сколько-нибудь интеллектуальных контекстах.

В целом несовпадение картины, которую поэт рисует в мемуapax, с той, что реконструируется из его писем, соответствует общей схеме подобных расхождений между книгой Хьюза и его эпистолярием: мемуары направлены «вовне», на описание страны или среды, более или менее случайной по отношению к поэту, которую он может описывать как посторонний, пикаро или трикстер. Его собственная жизнь тоже становится функцией описания советской действительности (жизнь у Кармонов позволяет рассказать о продуктовых карточках и магазинах, а жизнь в гостинице - о многочисленных иностранцах, посещающих СССР). Какие-то части этой жизни интерпретируются как случайность по отношению к этой действительности и обходятся молчанием.

Одним из таких важных московских эпизодов, практически обойденных в мемуарах, был, конечно, роман поэта с Сильвией Чен. Интенсивность этого романа, главным образом, реконструируется по письмам Хьюза Сильвии 1934-1936 гг., согласно публикаторам переписки, - самым проникновенным образцам его любовных писем, дошедших до нас [Rampersad 2015: 27; Rampersad 2002: 264-265, 268] ${ }^{11}$. В “I Wonder as I Wander" эта история не сообщается, зато подробно и иронично излагаются отношения с некоей Наташей, преследующей поэта своими чувствами. За пределами книги остается и постоянный дружеский круг «американской колонии», включавший редактора, журналистов и, вероятно,

11 В этой истории публичная репрезентация все время не совпадает с приватной: собственно любовный план восстанавливается из писем, отчасти вошедших в опубликованный том, отчасти пересказанных биографами [Rampersad; Leach 2004: 88-89; Mickenberg 2015: 23, 28-29], в то время как в публичных высказываниях оба они ничего не рассказывали о характере своих отношений (в мемуарах Сильвии Чен (Си-Лан Чен Лейда) говорится только о дружбе [Leyda 1984: 162-163]). 
других авторов журнала. Творческая жизнь Хьюза изображается как некое собрание спорадических встреч и озарений: Анисимов, Лидия Филатова, знакомство с рассказами Лоуренса, — а не регулярное взаимодействие с редакторами, что, впрочем, и не должно вызывать удивления читателя: общение с редактором - как правило, та часть творческого процесса, которую писатели предпочитают скрывать.

Один из важных моментов, которые открываются из чтения этой переписки, - это представление о том, как создавался московский «центр» «республики словесности», по Паскаль Казанова. Присутствие в Москве Уолта Кармона, тот тон, которым ведется переписка, заметно отличается от более официального, хотя и вполне дружеского тона письма Динамова, а рекомендации Кармона - от стандартного набора соображений директора института Красной профессуры. Благодаря американскому редактору, журнал «Интернациональная литература» в общении с авторами отказывается от официального и чрезмерно идеологизированного стиля советского издания в пользу гораздо более неофициального, а в данном случае и ярко индивидуального стиля, свойственного американским изданиям и привычного американским авторам. Среда московских космополитов, таким образом, становилась механизмом конвертации советского проекта в понятный американцу издательский продукт: англоязычная версия журнала «Интернациональная литература» существовала в том же коммуникативном пространстве, что и американские журналы, а по каким-то показателям даже их опережала (основным параметром неизменно являются гонорары).

Письмо Динамова написано по-русски и явно предназначалось для перевода. Оно не датировано, но с точностью до нескольких месяцев дату можно установить. Пьесы Хьюза, о которых пишет Динамов, написаны в 1936 году, как и стихотворение «Песня Испании» ("Song of Spain”), зачитанное автором еще летом 1936 года на массовом митинге Национального негритянского конгресса и Американского комитета помощи испанской демократии [Echevarría 2005: 93], а впервые опубликованное в шестом (июньском) номере журнала "International Literature" за 1937 г. (в США оно вышло на год позже, в составе сборника «Новая песня» (“A New Song”). При этом шестой номер «Интернациональной литературы» - предпоследний, где Динамов указан в качестве единственного редактора, в восьмом номере появляется Рокотов, с девятого имя Динамова исчезает с обложки журнала. Если для датировки пользоваться архивными документами, то это письмо явно помещается между письмом Динамова от 13-го мая 1937 года с просьбой прислать стихотворение в юбилейный номер к два- 
дцатилетию Октябрьской революции и письмом Тимофея Рокотова от 19-го сентября, оповещающего Хьюза, что стихотворение получено ${ }^{12}$.

Письмо Динамова демонстрирует уже другой характер взаимоотношений поэта с редакцией. Оно еще предполагает личные дружеские отношения; например, сетования на затянувшееся молчание - типичное общее место для московских корреспондентов поэта («Я был счастлив, что мог хотя бы так, косвенным образом услышать от Вас»), но совсем не предполагает амикошонского тона писем Кармона. Меняется и характер критики - на предсказуемые бинарные оппозиции и специфический новояз народившегося соцреализма (общественное важнее личного, эротическое грубовато и легкомысленно, трагедия гаитянского лидера Дессалина «в том, что он отрывается от своего народа» и т.п.). Динамов, как это свойственно ему в переписке, выступает как редактор, активно включающийся в творческий процесс авторов: не только позволяющий себе критику, но и дающий рекомендации (не уводить народ «за кулисы» пьесы, продолжить историю мальчика Сэнди из полюбившейся в СССР книги "Not Without Laughter"). Демонстрируя определенную степень личной вовлеченности, письмо в то же время весьма типично для рутинной переписки Динамова с иностранными авторами. Ретроспективно, однако, в нем читается неминуемая трагическая гибель, от которой Сергея Динамова отделяли лишь месяцы, и окончание «индивидуальной» эпохи «Интернациональной литературы», где личность главного редактора определяла редакционную политику и отчетливо проявлялась в его переписке. Его последователь на этом посту Тимофей Рокотов за несколько лет своего пребывания в этом кресле так и не получил официального статуса главного редактора, а его местами весьма оживленная и где-то даже сердечная переписка с авторами практически лишена отпечатка его индивидуального характера.

${ }^{12}$ РГАЛИ. Ф. 1397. Оп. 1. Ед. хр. 957. Л. 6-8. 
ПРИЛОЖЕНИЕ

\section{ПИСЬМА УОЛТА КАРМОНА ЛЭНГСТОНУ ХЬЮЗУ ${ }^{13}$}

Oct. 26, 1934

Dear Langston,

We were so surprised to hear from you we thought you might be sick or something and it was about time, you little shrimp!

Any way we're as pleased as devils and glad to have all that information about your activities. Rose was especially pleased to see that you are doing a new series of short stories 14 on more "Left themes" and don't give us that hooey about "a necessary part of my development" that's horses.

We are pleased as all hell to see that you get the breaks, you're getting in all the magazines, only honest kid don't let it spoil you ${ }^{15}$.

I am especially glad you sent on a piece about your Carmel experiences $^{16}$, I sent it to Comrade Dinamov and I am sure that it will go into our issues.

Are you serious about sending a piece especially for the English number - if you don't mean an article or short-story, isn't it time for us to get a piece of verse, maybe you've got something handy ${ }^{17}$.

Fred, Sylvia, Jack, Lucy, Ethel ${ }^{18}$ — all of them seem to be thriv-

13 РГАЛИ. Ф. 1397. Оп. 1. Ед. хр. 957. Л. 1-4. Текст - машинопись. Перевод писем мой. - Е.О.

${ }^{14}$ В автобиографии Хьюз связывает появление жанра рассказа в его творчестве с влиянием Д.Г. Лоуренса, которого он впервые прочел в СССР [Hughes 2003: 220].

15 Начиная с публикации написанного в СССР рассказа «Раб в колодках» ("Slave on the Block"), в сентябрьском номере журнала "Scribner" за 1933 г., рассказы Хьюза постепенно начинают проникать на страницы журналов, а написанный по возвращении сборник рассказов был немедленно принят к публикации. Арнольд Рэмперсед связывает коммерческий успех Хьюза не в последнюю очередь с усилиями его нового литературного агента Макса Либера и описывает ситуацию 1933-1934 гг. почти в тех же выражениях, что и Кармон: «Прорвавшись столь уверенно (in breaking so consistently) на страницы крупных журналов, Хьюз [...] выступил как профессиональный писатель. [...] Хьюз, более того, выступил как профессиональный писатель, не поступаясь своими радикальными принципами» [Rampersad 2002: 281, 285].

${ }^{16}$ Имеется в виду очерк «“Блюстители закона” стучатся в мою дверь», опубликованный в шестом номере русского издания за 1934 г.: Хьюз Л. «Блюстители закона» стучатся в мою дверь / Пер. с американской рукописи Э. Бер. С. 96-98.

${ }^{17}$ В 1933-1934 гг. Хьюз пишет и публикует в основном прозу.

18 Фред и Этель Эллис, «популярная американская чета», как пишет о них Рэмперсед в биографии Хьюза [Rampersad 2002: 271]; Фред Эллис - 
ing and all of them send best wishes as well as hope of seeing you soon. I don't know about the apartment "for a FOREIGN WRITER", but you can always SIT in our office.

I have heard from Norman McCleod recently and he was good enough to send on his book of verse, I wished it was more book and less [нрзб] some of the stuff there seems quite good - meanwhile he writes me that he is on the wagon and seems quite active.

Things here are improving so steadily that even the piroznia are better, but it is your own fault we warned you not to leave when you did. Tonite we are going over to Fred Ellis's - so that's just another thing you are missing.

Write again soon wont' you? Rose and I send our love and all of the gang want to be remembered.

\section{Дорогой Лэнгстон!}

Мы так удивились, получив твое письмо, мы уж думали, что ты заболел или еще чего, а давно бы уже пора, креветка ты этакая!

Ну, да мы все равно довольны, как черти, и рады и, что теперь располагаем всей информацией о том, чем ты занят. Роуз особенно обрадовало, что ты пишешь новую серию рассказов на другие «левые темы», и хватит этой чуши о «необходимой стадии моего развития», это все бред собачий.

Мы рады до чертиков, что тебе везет и тебя печатают во всех журналах, но только, не позволяй им испортить тебя, честный малый.

Особенно я рад, что ты прислал нам рассказ о том, что ты видел в Кармеле, я отправил его товарищу Динамову, и уверен, что он пойдет в наши издания.

Ты серьезно обещал нам прислать что-нибудь специально для английского номера - если ты не имел в виду рассказ или статью, то не пора ли нам получить твои стихи, может у тебя есть что-то под рукой?

Фред, Сильвия, Джек, Люси, Этель - все они, кажется, прекрасно поживают и все шлют тебе наилучшие пожелания и говорят, что надеются вскоре тебя увидеть. Не знаю, как насчет квартиры «для ИНОСТРАННОГО ПИСАТЕЛЯ», но ты всегда можешь СИДЕТЬ в нашем офисе.

Недавно мне написал Норман Маклеод и любезно прислал мне книгу своих стихов, жаль, что это не столько книга, сколько

американский радикальный карикатурист, в 1930-1936 жил в Москве и Берлине; принадлежал к кругу авторов «Интернациональной литературы». Джек и Сильвия Чены - двое из четырех детей Юджина Чена, экс-министра Китая; Люси - жена Джека. 
$<$ нрзб>, что-то из нее очень неплохо - между тем, он пишет, что он в обойме и, похоже, весьма активен.

Здесь все настолько хорошеет, что даже piroznia ${ }^{19}$ стали лучше, но ты сам виноват, мы предупреждали, что не надо было уезжать, а ты все-таки уехал. А сегодня мы все идем к Фреду Эллису — и это ты тоже пропускаешь!

Отвечай поскорее, ладно? Мы с Роуз шлем горячий привет, и вся честная компания просит, чтобы и их не забыли.

Dec. 9, 1934

Langston Hughes

Box 1582

Carmel, Calif.

Dear Lang:

Good to hear from you again. Better still to hear about the new stories of the "struggle" which you are about to send to your agent. You little bastard: if you don't send on copies of these stories quickly I will bite a hole in some of the books all of which are here waiting for you. I will forgive you for a lot of things if you send on the story or article which you promised to do especially for the English edition. Until then you've got a kick in the pants coming to you.

I was delighted to see the headway you're making in the magazines and more delighted to see that beside that fact you're not getting soft but are doing even better stories up our alley.

I thought your "Ballad on Roosevelt" in the New Republic was just swell, one of the neatest things of yours I have seen for sometime. Rose joins me in my enthusiasm.

Thanks for sending on the item about Jacque Romain ${ }^{20}$. This has already been retyped and goes into all our issues including the English one now on the press. Meanwhile we will see that it gets into the "Literary Gazette" and I will send on a copy to the "Moscow Daily News" ${ }^{21}$. So it will be taken care of.

19 По-видимому, имеются в виду пирожные.

${ }^{20}$ Письмо Хьюза с выражением протеста против ареста Жака Румена, гаитянского поэта и писателя, основателя коммунистической партии Гаити, было опубликовано в № 6 «Интернациональной литературы» за 1934 год. Хьюз переводил Ромена.

${ }^{21}$ B “I Wonder as I Wander" Хьюз описывает “Moscow Daily News" как пропагандистское издание, которое не читали в «американской колонии», в котором, однако всегда помогали попавшим в беду ("It was a kind of Travelers’ Aid Bureau” [Hughes 2002: 215]). 
I saw the reviews of Jo Herbst's book ${ }^{22}$ and since I have just seen all that makes me anxious to get at the novel. A quick glance over makes me think it is worth reading.

Tretiakov was delighted to receive the clippings that you sent to him and of course he and all of us send warmest regards.

I don't know what special news I can give you. Both the English and Russian sheets become monthly's at the beginning of this year. So you see that we will need your help more than ever: stray pieces of verse as well as prose. In the new Russian issue is a half dozen of your things and we will be sending you a copy.

Jack Chen is the proudest papa I have ever seen, Sylvia is going to have a concert soon, Tretiakov is planning to go the States, Rose has been feeling much better than usual, I am getting fatter than hell, it is getting colder than billy-be-damned - we have to SIT as much as ever for our rubles and we'd all like to see you here soon.

Let's hear from you. Best wishes. Walt Carmon

Дорогой Лэнг!

Приятно услышать от тебя ${ }^{23}$. Еще приятнее услышать о новых рассказах «о борьбе», которые ты собираешься отправить своему агенту. Негодяй, если ты не пришлешь нам эти рассказы, и побыстрее, я прогрызу дырки в книгах, которые, кстати, все тут тебя дожидаются. Я многое готов простить, если ты пришлешь рассказ или статью, что ты обещал для английского номера. А пока тебя ожидает хороший пинок.

Я в восторге от твоего успеха в журналах, и в еще большем восторге, что, несмотря на это, ты не стал размазней, и твои рассказы по нашему ведомству стали только лучше.

Твоя «Баллада о Рузвельте» в «Нью Репаблик» просто прекрасна, одна из лучших твоих вещей, что я читал в последнее время. И Роуз разделяет мой энтузиазм.

Спасибо, что прислал эссе о Жаке Румене. Оно уже перенабрано и пойдет во все наши номера, в том числе английский, который сейчас в печати. Меж тем, я займусь тем, чтобы поместить его в «Литературной газете» и отправлю копию в «Moscow Daily News». Так что это будет сделано.

22 Джозефина Хербст - американская писательница и журналист. В 1933 году она опубликовала роман «Жалости мало» (“Pity is not enough"), а в 1934 - «Палач ждет» (“The Executioner Waits”), они составляют первую и вторую часть трилогии. Не вполне понятно, о каком из двух романов идет речь.

23 Здесь переводчик вдохновляется стилем письма С. Динамова и использует его фразу. 
Я видел рецензии на книгу Джо Хербст и с тех пор мечтаю заполучить сам роман. При беглом взгляде кажется, что его стоит прочитать.

Третьяков был в восторге от вырезок, которые ты ему прислал, и, конечно, он и вся редакция передают горячий привет.

Не знаю, какие особые новости я могу тебе сообщить. И русский, и английский журнал становятся ежемесячными с начала года. Так что, как видишь, нам, как никогда, понадобится твоя помощь: непристроенные стихотворения, да и проза. В новом русском номере с полдюжины твоих вещей, так что мы пришлем тебе экземпляр.

Джек Чен - самый гордый отец, которого мне приходилось видеть. У Сильвии скоро будет концерт. Третьяков планирует поездку в штаты, Роуз чувствует себя лучше, чем когда-либо, я становлюсь толст, как черт, становится холоднее, чем черт-знаетгде - нам приходится СИДЕТЬ, как никогда, за свои рубли, и мы все хотели бы увидеть тебя здесь.

Жду ответа. Наилучшие пожелания.

Уолт Кармон

December 29, 1934

Dear Lang:

Thanks a lot for the copies of the 3 stories. I am going to do what I can with them. I should think that "Professor" should be useful for our Russian and other editions, I am so suggesting to Comrade Dinamov.

Your "Oyster's Son" and "The Sailor and the Steward" I like much less and in the order named. I never had occasion to criticize you on this before, but they are too agit-prop - in the cruder sense; I remember a much better piece on "Waldorf-Astoria".

Anyway I am going to hand out both stories for possible publication - if not in our sheets than to some others.

Incidentally Rose agrees entirely with my opinion of the stories. She sends best regards as do all of us.

If you get an extra copy of TRAVEL magazine with your story in it by all means send it on.

How is the book coming on? And whatever has happened to the book of verse.

I'll be seeing Lydia Mirtsova ${ }^{24}$ in the next day or two and I'll be sure to give your regards.

${ }^{24}$ Переводчица, с которой Хьюз познакомился еще в составе группы по- 
Haven't you heard that Lydia Filatova is dead? She has been for nearly a year - went out like a light within one week. over?

Let's hear from you again and how are your plans about coming

Best wishes, Walt Carmon.

29 декабря 1934 г.

Дорогой Лэнг!

Большое спасибо, что прислал 3 рассказа. Я сделаю с ними, что могу. Думаю, что «Профессора» мы сможем использовать в нашем русском и других изданиях. Я предложу это товарищу Динамову.

Твои «Солнце устрицы» и «Моряк и стюард» мне нравятся гораздо меньше и именно в таком порядке. Мне еще никогда не доводилось критиковать тебя за это, но это откровенная агитка в самом грубом смысле слова. Я помню вещь много лучше о «Уолдорф-Астории».

В любом случае, я собираюсь отдать оба рассказа для публикации - если не на наших страницах, то где-нибудь еще.

Между прочим, Роуз полностью со мной согласна в оценках рассказов. Она передает наилучшие пожелания, как и все мы.

Если тебе удастся добыть лишний экземпляр «Трэвел» с твоим рассказом, конечно же, присылай его.

Как продвигается книга? И что там случилось со сборником стихов?

На днях я встречаюсь с Лидией Мирцовой и, конечно, передам ей от тебя привет.

Ты не слышал, что Лидия Филатова умерла? Уже почти год назад: сгорела, как свечка, за неделю.

Ждем от тебя вестей, и какие у тебя планы на приезд сюда?

Наилучшие пожелания, Уолт Кармон.

тенциальных участников фильма, она же в качестве переводчика сопровождала группу в поездке в Среднюю Азию. [Rampersad 2002: 249, 254]. 


\section{ПИСЬМО СЕРГЕЯ ДИНАМОВА ЛЭНГСТОНУ ХЬЮЗУ 25}

Лэнгстону Хьюзу

(care of Maxim Lieber, 545 Fifth Avenue, New York City, USA)

Дорогой Лэнгстон,

Мне удалось прочесть за последнее время две Ваших пьесы: комедию, написанную Вами совместно с Арна Бонтемпс, и Вашу историческую драму “Troubled Island”. Я был счастлив, что мог хотя бы так, косвенным образом услышать от Вас, - ведь со времени Вашего отъезда из СССР Вы не балуете нас известиями о себе. А между тем, Вы должны знать, как близко принимают к сердцу Ваши здешние друзья все, что касается Вас и Вашего творчества.

Ваша комедия "When the Jack Hollers" очень красочна и местами очень забавна. Быть может, я ошибаюсь, но мне кажется, однако, что она выиграла бы, если бы Вас не связывало сотрудничество с Арна Бонтемпс (я должен признаться, что у меня осталось не самое блестящее воспоминание о "Роро and Fifina", написанной Вами совместно с ним). Самое лучшее в Вашей комедии, на мой взгляд, это - третий акт, где так правдиво и убедительно показано братание белых и черных sharecropper'ов. Вот мотив, который хотелось бы еще больше акцентировать и сделать основным стрежнем пьесы. Что же касается эротики, которой так щедро пропитана Ваша комедия, то мне кажется, что она принижает ее значение. Дело даже не столько в грубоватости этой эротики, сколько в том, что она дает возможность «белым зрителям» по традиции пожимать плечами и подсмеиваться над легкомыслием «этих негров». В Вашем романе "Not Without Laughter", в Ваших рассказах и стихах, Вы умели находить другой, более серьезный и искренний тон. Этот тон Вы находите и здесь, в третьем акте и, отчасти, и в других местах Вашей комедии; но мне кажется, что он, к сожалению, слишком часто бывает заглушен «криком осла» ("the jack").

Я лишь в общих чертах знаком с историей негритянского восстания на Гаити, которое служит темой Вашего "Troubled Island", - мне кажется, однако, что она хорошо передает колорит эпохи. Во всяком случае, на меня она произвела большое впечатление. В истории Дессалина (Dessalines) есть действительный трагизм. Жаль только, что Ваша драма, начатая как драма широкого народного восстания, очень скоро сужается до пределов драмы

${ }^{25}$ РГАЛИ. Ф. 1397. Оп. 1. Ед. хр. 957. Л. 22. 
одной личности. Трагедия Дессалина была в том, что он оторвался от своего народа; но значит ли это, что народ должен был поэтому уйти за кулисы Вашей пьесы?

Что Вы писали еще за последнее время, Лэнгстон? Нет ли у Вас новых стихов? Пьесы, как Вы знаете, вообще не особенно благодарный материал для журнала. Ваши стихи были бы для нас находкой.

Когда-то, помните, Вы думали о том, чтобы продолжить дальше историю мальчика Сэнди (Sandy), начатую в "Not Without Laughter". Думаете ли Вы об этом и теперь? Мне кажется, это была бы очень интересная и нужная творческая задача.*

Надеюсь, что когда-нибудь Вы, наконец, нарушите Ваше молчание и дадите мне услышать хоть что-нибудь от Вас. С сердечным приветом, С. Динамов

[от руки] PS. Только что получил Ваше стихотворение "Song of Spain”. Спасибо! Мы, конечно, напечатаем его в «Интернациональной литературе».**

\section{REFERENCES}

[Baldwin 2002] — Baldwin, Kate. Beyond the Color Line and the Iron Curtain: Reading Encounters between Black and Red, 1922-1963. Durham (NC): Duke University Press, 2002.

[Baldwin 2007] - Baldwin, Kate. "The Russian Connection: Interracialism as Queer Alliance in The Ways of White Folks." Montage of a Dream: The Art and Life of Langston Hughes, ed. by C. Ragar, J.E. Tidwell. Columbia (MO): University of Missouri Press, 2007.

[Bontemps \& Hughes 1980] - Bontemps, Arna Wendell; Hughes, Langston. Letters, 1925-1967, ed. by Charles H. Nichols. N.Y., Dodd, Mead, 1980.

[De Santis 1995] - De Santis, Christopher C. Langston Hughes and the Chicago Defender: Essays on Race, Politics, and Culture, 1942-62. Urbana (IL): University of Illinois Press, 1995.

[Echevarría 2005] - Echevarría, Luis Gustavo Girón. "Langston Hughes’s Spanish Civil War Verse." Anuario de Estudios Filológicos. 28 (2005): 91-101.

[Hughes \& Van Vechten 2002] — Hughes, Langston, Van Vechten, Carl. Remember Me to Harlem: The Letters of Langston Hughes and Carl Van Vechten, ed. by Emily Bernard. New York: Vintage, 2002.

[Hughes 1934] - Hughes, Langston. A Negro Looks at Soviet Central Asia. Moscow: Co-operative Pub. Society of Foreign Workers in the U.S.S.R., 1934.

[Hughes 2003] - Hughes, Langston. "I Wonder as I Wander." Hughes, Langston. Collected Works. Vol. 14. Columbia and London: University of Missouri Press, 2003.

[Hughes 2010] - Hughes, Langston. 2010. Langston Hughes and the South African Drum Generation : The Correspondence. New York : Palgrave Macmillan, 2010.

[Hughes 2015] - Hughes, Langston. Selected Letters. New York: Alfred A. Knopf, 2015.

* [Стрелка вынос, от руки]: по-моему, стоит напечатать.

** [Вынос, от руки]: Под моей редакцией скоро сдается в печать большая антология негрит[янской]. поэзии, куда вошли, конечно, и В[аши] стихи. 
[Hughes 2016] - Hughes, Langston. Letters from Langston: From the Harlem Renaissance to the Red Scare and Beyond, ed. by Evelyn Louise Crawford, Mary Louise Patterson. M.D. Oakland (CA): University of California Press, 2016.

[Leach 2004] - Leach, Laurie F. Langston Hughes: A Biography. Westport (CT): Greenwood Publishing Group, 2004.

[Leyda 1984] — Leyda, Si-Lan Chen. Footnote to History. New York: Dance Horizons, 1984.

[Lipovetsky 2011] — Lipovetsky, Mark. Charms of the Cynical Reason: the Trickster's Transformations in Soviet and Post-Soviet Culture. Boston (MA): Academic Studies Press, 2011.

[Mickenberg 2015] - Mickenberg, Julia. "To Be His Storm over Asia": American Women, Sex, and Revolutionary Tourism in Russia, 1905-1945. Red Love Across the Pacific: Political and Sexual Revolutions of the Twentieth Century, ed. by Ruth Barraclough, Heather Bowen-Struyk, Paula Rabinowitz: New York: Palgrave Macmillan, 2015: 15-29.

[Moore 2002] - Moore, David C. "Colored Dispatches from the Uzbek Border: Langston Hughes' Relevance, 1933-2002.” Callaloo 25:4 (Fall 2002): 1115-1135.

[Rampersad 2002] — Rampersad, Arnold. The Life of Langston Hughes: Vol. I: "19021941. I, Too, Sing America". $2^{\text {nd }}$ ed. New York: Oxford University Press, 2002.

[Rampersad 2015] - Rampersad, Arnold. "Introduction.” Hughes, Langston. Selected Letters. New York: Alfred A. Knopf, 2015: 8-28.

[Rampersad, Roessel, \& Fratantoro 2015] - Rampersad, Arnold, Roessel, David, and Fratantoro, Christa. "Editorial Preface." Hughes, Langston. Selected Letters. New York: Alfred A. Knopf, 2015: 29-33.

[Wald 2002] - Wald, Alan. Exiles from A Future Time: the Forging of the MidTwentieth-Century Literary Left. Chapel Hill (NC) : University of North Carolina Press, 2002. 